\title{
Constructing International Criminal Justice across Time and Space
}

\author{
Emma Palmer ${ }^{1}$
}

\begin{abstract}
Scholars have suggested that ratifying international treaties and implementing them within national legal systems can lead to the acceptance and (eventually) internalisation of international norms. Likewise, failing to ratify might suggest that states reject such norms. Similarly, ratifying the Rome Statute is often promoted as the primary measure to give effect to the norms protected by international criminal law. This perspective of the diffusion of international criminal justice involves at least three characteristics. First, a temporal aspect, in that states are expected to progress from rejecting international criminal justice toward acceptance over time. Second, it reveals a spatial awareness, including by distinguishing between international and 'local' norms and actors. Third, this approach includes assumptions about the movement of ideas across both time and space, or directionality. This article challenges temporal, spatial, and directional assumptions about how states engage with international criminal justice with reference to experiences in Southeast Asia.
\end{abstract}

\section{Introduction}

In 2017 alone, Duterte's government was implicated in the deaths of possibly 12,000 or more alleged drug users and dealers within the Philippines ${ }^{2}$ and hundreds of thousands of members of the Rohingya minority fled violence in Burma. ${ }^{3}$ Since 2000, hundreds of thousands have been forcibly evicted from their lands in Cambodia (and elsewhere in the region) ${ }^{4}$ and in Indonesia past human rights abuses, including mass killings in 1965, as well as more recent

\footnotetext{
${ }^{1}$ With thanks to Sarah Williams, Andrew Byrnes, Philipp Kastner, Sean Richmond, Holly Cullen, and the anonymous reviewers and editors for their extremely useful comments, corrections and suggestions. All remaining errors and omissions are my own.

${ }^{2}$ L. Murdoch, 'It's unacceptable children are deemed collateral damage in Duterte's war on drugs', The Sydney Morning Herald, 24 August 2017, <www.smh.com.au/world/its-unacceptable-children-are-deemed-collateraldamage-in-dutertes-war-on-drugs-20170824-gy305e>, accessed 12 March 2018.

${ }^{3}$ AFP-SBS Wires, 'Myanmar and Bangladesh sign deal to return hundreds of thousands of Rohingya refugees', 24 November 2017, <www.sbs.com.au/news/article/2017/11/23/myanmar-and-bangladesh-sign-deal-returnhundreds-thousands-rohingya-refugees>, accessed 12 March 2018. 'Myanmar' is used for modern 'Burma', consistent with official and UN usage.

${ }^{4}$ GRAIN, 'Asia's agrarian reform in reverse: laws taking land out of small farmers' hands', 30 April 2015, $<$ www.grain.org/article/entries/5195-asia-s-agrarian-reform-in-reverse-laws-taking-land-out-of-small-farmershands>, accessed 12 March 2018.
} 
events, remain unresolved. ${ }^{5}$ How could, or should, the perpetrators of this violence be prosecuted? Which actors are involved and what strategies do they develop to seek the prosecution of atrocity crimes?

The politics of international criminal law is intertwined with questions about the spread of international norms - in particular, how states may come to accept or internalise international legal obligations. Scholars have recognised that a version of 'international criminal justice' involving the use of 'international' institutions to prosecute individuals for these types of serious violence might be considered 'normalized', ${ }^{6}$ particularly since the establishment of the International Criminal Court (ICC). Some constructivist norm diffusion theories suggest that international criminal justice is obtained over time ${ }^{7}$ through interaction between spatially differentiated actors and ideas, ${ }^{8}$ which encourages the external idea to flow in the direction of receiving locals. ${ }^{9}$ This suggests a linear path where, with the influence of civil society and other states, states progress from rejecting the Rome Statute toward inclusion within the ICC framework, represented by ratification or (at least) the adoption of domestic laws that closely replicate the international model. However, this article argues that legal responses to atrocity crimes do not only result from international norms being transmitted to receptive locals.

\footnotetext{
${ }^{5}$ See R. Cribb, 'The Indonesian Massacres' in S. Totten and W. S. Parsons (eds.), Century of Genocide (Routledge, New York, 2009) 193-217; Komnas-HAM, 'Statement by Komnas-HAM (National Commission for Human Rights) on the Results of Its Investigations into Grave Violation of Human Rights During the Events of 1965-1966 (Unofficial Translation)', <www.etan.org/action/SaySorry/Komnas\%20HAM\%201965\%20TAPOL\%20translation.pdf>, accessed 12 March 2018; Marlies Glasius, Foreign Policy on Human Rights: Its Influence on Indonesia under Soeharto (Intersentia, 1999), p. 33.

${ }^{6} \mathrm{~F}$. Mégret, 'In defense of hybridity: towards a representational theory of international criminal justice' 38(3) Cornell International Law Journal (2005) 725-751; see also C. Epstein, 'The postcolonial perspective: an introduction' 6(2) International Theory (2014) 294-311.

${ }^{7}$ E.g., M. Koskenniemi, 'Law, Teleology and International Relations: An Essay in Counterdisciplinarity', 26(1) International Relations (2012) 3-34; L. Zimmermann, 'Same Same or Different? Norm Diffusion Between Resistance, Compliance, and Localization in Post-conflict States', International Studies Perspectives (2014) 119; and in relation to history(/ies), see G. Simpson, 'Linear law: The history of international criminal law', in C. Schwöbel (ed.), Critical Approaches to International Criminal Law (Routledge, Milton Park, 2014) pp. 159-179; M. Craven, M. Fitzmaurice and M. Vogiatzi, Time, History and International Law (Martinus Nijhoff, Leiden, 2007).

${ }^{8}$ S. Buckley-Zistel, 'Frictional spaces: Transitional justice between the global and the local,' in A. Björkdahl et al (eds.), Peacebuilding and Friction: Global and Local Encounters in Post Conflict-Societies (Routledge, Milton Park, 2016) pp. 17-31; R. Hughes, 'Dutiful tourism: Encountering the Cambodian genocide', 49(3) Asia Pacific Viewpoint (2008) 318-330; A. Riles, 'The View from the International Plane: Perspective and Scale in the Architecture of Colonial International Law', 6(1) Law and Critique (1995) 39-54; R. Shaw, L. Waldorf and P. Hazan (eds.), Localizing Transitional Justice: Interventions and Priorities after Mass Violence (Stanford University Press, Stanford, 2010).

${ }^{9}$ A. Acharya, 'How Ideas Spread: Whose Norms Matter? Norm Localization and Institutional Change in Asian Regionalism', 58(2) International Organization (2004) 239-275; A.L. Hinton, 'Introduction: Toward an Anthropology of Transitional Justice', in A.L. Hinton (ed.), Transitional Justice: Global Mechanisms and Local Realities after Genocide and Mass Violence (Rutgers University Press, New Brunswick, 2010) pp. 1-22.
} 
Instead, they are developed and modified by a range of actors who adapt arguments and persist with advocacy efforts over time, across different spaces, and within changing circumstances.

In light of historic and more recent atrocities, the underrepresentation of states in Southeast $\mathrm{Asia}^{10}$ as parties to the Rome Statute has elicited concerns that the region is 'seriously lagging behind in international criminal law ${ }^{11}$ and there have been efforts to encourage ratification of the Statute within the region. However, while only Cambodia, Timor-Leste and the Philippines have ratified the Rome Statute, Southeast Asia has been the site of two internationalised tribunals, the Extraordinary Chambers in the Courts of Cambodia (ECCC) and Special Panels of the District Court of Dili (SPs), and five regional states have criminal legislation addressing international crimes. ${ }^{12}$ This raises questions about how different actors in Southeast Asia engage with international criminal justice.

This article draws on an analysis of national legislation, government statements, NGO reports, and discussions in Southeast Asia - held especially with civil society actors in Cambodia, the Philippines, Indonesia, and Myanmar - to challenge assumptions concerning the temporal progression, spatial divisions, and direction of the diffusion of international criminal justice. It begins by discussing how international criminal justice is conventionally understood within international relations constructivist frameworks. It then analyses what such an approach suggests about the temporal, spatial, and directional nature of its diffusion, including in Southeast Asia. Finally, this article argues for a more nuanced account of how encounters between different actors across time and space affect responses to international crimes, recognising that the power to shape discourse about international criminal justice arises from multiple shifting sources.

\footnotetext{
10 The ASEAN states and Timor-Leste.

${ }^{11}$ Sang-Hyun Song, Role of Asian Lawyers in the Emerging System International Criminal Justice, p. 2, <www.icc-cpi.int/iccdocs/PIDS/press/WU99/111010ICCPresidentkeynotespeech.pdf>, accessed 12 March 2018.

${ }^{12}$ Cambodia (Criminal Code of the Kingdom of Cambodia, 2009), Timor-Leste (Penal Code in Timor-Leste, Decree Law 19 of 2009), the Philippines (Philippine Act on Crimes Against International Humanitarian Law, Genocide, and Other Crimes Against Humanity, Republic Act 9851, December 2009 (Philippines IHL Act)), Indonesia (Law on Human Rights Courts, Law No. 26, 2000, Republic of Indonesia (Law 26/2000)); and Vietnam (Socialist Republic of Viet Nam, Penal Code, No. 15/1999/QH10 (Vietnam Code)). Singapore's Penal Code also includes an offence of genocide in section 130D Penal Code, Ordinance 4 of 1871, Revised 2008, An Act to Consolidate the Law Relating to Criminal Offences, while grave breaches are included in the 1973 Geneva Conventions Act - and in section 3, Geneva Conventions Act 1962 (Revised 1993) of the Republic of Malaysia.
} 


\section{The Diffusion of International Legal Norms}

The development of international criminal law shifted the historic emphasis of international law upon state responsibility toward holding individuals accountable for their crimes, often with international involvement and in post-conflict settings. This 'norm cascade' ${ }^{13}$ has been described as being 'embodied' in the establishment of the ICC, its principle of complementarity, and the progressive ratification of the Rome Statute across the world. ${ }^{14}$ The same period saw the proliferation of theoretical approaches to international law, including (despite early divisions between the two 'disciplines' ${ }^{15}$ with reference to international relations scholarship, including that of constructivism. ${ }^{16}$

The broad array of constructivist perspectives identifies relationships between widely held intersubjective ideas (norms), such as international criminal justice, substantive international law, and legal compliance. One prominent branch includes norm diffusion and processoriented frameworks for explaining legal compliance. ${ }^{17}$ Such approaches, for instance those proffered by Koh and Goodman and Jinks may focus upon and favour the adoption of particular norms, such as encouraging states to comply with international human rights laws. ${ }^{18}$ They may take a 'managerialist' approach, assuming that 'the objectives of institutional action are given and the only remaining questions concern their manner of optimal realisation'. ${ }^{19}$ As a result, some constructivist approaches may be oriented toward

\footnotetext{
${ }^{13}$ M. Finnemore and K. Sikkink, 'International Norm Dynamics and Political Change', 52(4) International Organization (1998) 887-917.

${ }^{14}$ M.J. Struett, The Politics of Constructing the International Criminal Court: NGOs, Discourse, and Agency (Palgrave Macmillan, New York, 2008), p. 23; e.g. Coalition for the International Criminal Court (CICC), Universality and implementing the Rome Statute - What are the challenges?, 2015, < ciccglobaljustice.wordpress.com/2015/09/24/universality-and-implementing-the-rome-statute-what-are-thechallenges/>, accessed 12 March 2018; B. Schiff, Building the International Criminal Court (Cambridge University Press, Cambridge, 2008), p. 248.

${ }^{15}$ D.J. Bederman, 'Constructivism, Positivism, and Empiricism in International Law', 89 The Georgetown Law Journal (2000-2001) 469-499, p. 469; H.H. Koh, 'Why Do Nations Obey International Law?', 106 Yale Law School Legal Scholarship Repository (1997) 2599-2659, pp. 2615-2616.

${ }^{16}$ See A.-M. Slaughter, A.S. Tulumello and S. Wood, 'International Law and International Relations Theory: A New Generation of Interdisciplinary Scholarship', 92(3) American Journal of International Law (1998) 367-387; Bederman, supra note 15.

${ }^{17}$ These approaches are sometimes termed 'mainstream' constructivist theories: M. Weber, 'Between "Isses" and "Oughts": IR Constructivism, Critical Theory, and the Challenge of Political Philosophy', 20(2) European Journal of International Relations (2013) 516-543. For a discussion of the problematic nature of the term 'mainstream', see J. d'Aspremont, 'Martti Koskenniemi, the Mainstream, and Self-Reflectivity', 29(3) Leiden Journal of International Law (2016) 625-639, pp. 627-628.

${ }^{18}$ R. Goodman and D. Jinks, Socializing States: Promoting Human Rights through International Law (Oxford University Press, 2013); Koh, supra note 15.

${ }^{19}$ M. Koskenniemi, The Politics of International Law (Hart Publishing, Oxford, 2011), p. 46.
} 
specific policy recommendations, such as that states comply with certain norms, ${ }^{20}$ which might be promoted by treaties and international law-making practices.

Other constructivist scholars emphasise power relationships and may take a Marxist, feminist or 'third world' perspective or may distance themselves from 'constructivism' altogether. ${ }^{21}$ For example, postcolonial scholars critique 'mainstream' or 'first wave' ${ }^{22}$ constructivist literature by pointing to the 'norm diffusion' embodied by colonialism, which 'bore all the trappings of "appropriateness", ${ }^{23}$ as well as the "contiguity between liberalism and constructivism' in favouring universalisms. ${ }^{24}$ Some have emphasised the 'value-laden quality of criminal law' and the significance of power relationships in exercising justice. ${ }^{25}$ Thus, constructivism is diverse. Bearing this caveat in mind, constructivism 'rejects a simple law/power dichotomy, arguing instead that legal rules and norms operate by changing interests and thus reshaping the purposes for which power is exercised' ${ }^{26}$

In the international criminal law sphere, a constructivist approach will therefore be concerned with identities and the role of norms - such as the importance of ending impunity for serious violence - in shaping state behaviour. Scholars such as Mégret, Nouwen, Werner, Tallgren have drawn attention toward the relationship between international criminal law institutions such as the ICC and conceptions of 'global justice'. ${ }^{27}$ While they do not take an explicitly constructivist approach ${ }^{28}$ this scholarship has highlighted the discursive means that promote the dominance and normalisation of the international criminal justice norm.

\footnotetext{
${ }^{20}$ On the relationships between sociolegal scholarship, policy, politics and law, see A. Sarat and S. Silbey, 'The Pull of the Policy Audience', 10(2-3) Law \& Policy (1988) 97-166; see also R. Price 'Moral Limit and Possibility in World Politics', 62(2) International Organizations 191-220; Weber, supra note 17.

${ }^{21}$ R. Price and C. Reus-Smit, 'Dangerous Liaisons?: Critical International Theory and Constructivism', 4(3) European Journal of International Relations (1998) 259-294, p. 260; see Epstein, supra note 6; A. Anghie and B.S. Chimni, 'Third World Approaches to International Law and Individual Responsibility in Internal Conflicts', 2 Chinese Journal of International Law (2003) 77-103.

${ }^{22}$ A. Acharya, Rethinking Power, Institutions and Ideas in World Politics: Whose IR? (Routledge, Milton Park, 2014), p. 185

${ }^{23}$ Epstein, supra note 6, 301; Finnemore and Sikkink, supra note 13.

${ }^{24}$ Epstein, supra note 6, p. 298.

${ }^{25}$ K.W. Abbott, 'International Relations Theory, International Law, and the Regime Governing Atrocities in Internal Conflicts', 93 American Journal of International Law (1999) 361-379, p. 375; R. Palan, 'A world of their making - an evaluation of the constructivist critique in International Relations', 26(4) Review of International Studies (2000) 575-598, p. 586 .

${ }^{26}$ Slaughter, Tulumello and Wood, supra note 16, p. 381.

${ }^{27}$ S.M.H. Nouwen and W.G. Werner, 'Pursuing Global Justice Through International Criminal Law: Foreword', 13 Journal of International Criminal Justice (2015) 73-75, p. 73: and see the Special Issue introduced by this Foreword.

${ }^{28}$ Michelle Burgis-Kasthala, 'Scholarship as Dialogue? TWAIL and the Politics of Methodology' 14(4) Journal of International Criminal Justice (2016) 921-937; see Zimmermann, supra note 7; E. Palmer, 'Localizing
} 
A constructivist approach is appropriate for analysing how states' positions toward prosecuting international crimes might change - including to interrogate any emphasis upon the Rome Statute and ICC as the primary means for diffusing international criminal justice norms within Southeast Asia. Nevertheless, the following section introduces several implications of such scholarship for the field of international criminal justice that have been relevant in arguments surrounding the Rome Statute in Southeast Asia.

\subsection{Temporal Aspects}

A concern to explain why the spread of international criminal justice might have stalled in the Asia region has led scholars to ask 'What are the main factors inhibiting the other Southeast Asian states from accepting the [ICC]? ${ }^{29}$ or to discuss 'possible reasons for this reluctance on the part of Asia-Pacific countries to embrace the Court' ${ }^{30}$ - and to then address such concerns. ${ }^{31}$ That is, to consider how these states could progress from rejecting international criminal justice toward accepting it over time.

Time may be defined as a 'finite extent or stretch of continued existence, as the interval separating two successive events or actions, or the period during which an action, condition, or state continues'. ${ }^{32}$ Thus, 'time' involves a 'period' or 'stretch' within, or surrounding which, events take place, although actions may also occur 'at' a particular time. In this sense, time may be temporary or long-lasting, but typically has boundaries. Time also lacks normative content, in the sense that the passage of time in and of itself does not connote an improvement in the events or actions that it bounds.

\footnotetext{
International Criminal Accountability in Cambodia', 16 International Relations of the Asia-Pacific (2016) 97-135 as examples of constructivist scholarship addressing international criminal law.

${ }^{29}$ V. Toon, 'International Criminal Court: Reservations of Non-State Parties in Southeast Asia', 26(2) Contemporary Southeast Asia (2004) 218-232, p. 219.

${ }^{30} \mathrm{~S}$. Freeland, 'International Criminal Justice in the Asia-Pacific Region: The Role of the International Criminal Court Treaty Regime', 11(5) Journal of International Criminal Justice (2013) 1029-1057, p. 1031.

${ }^{31}$ Or to 'examine the reasons for reluctance to ratify the Rome Statute in specific politicocultural contexts', M. Findlay, 'Sign up or Sign off - Asia's reluctant engagement with the International Criminal Court', 13(44) Sydney Law School Legal Studies Research Paper (2013), p. 3; L. Schuldt, 'Southeast Asian Hesitation: ASEAN Countries and the International Criminal Court', 16(1) German Law Journal (2015) 75-105; A. Kapur, 'Asian Values v. The Paper Tiger: Dismantling the Threat to Asian Values Posed by the International Criminal Court', 11(5) Journal of International Criminal Justice (2013) 1059-1090.

32 Oxford English Dictionary.
} 
However, constructivist scholars often present states' adoption of international legal obligations as proceeding along 'a linear scale from resistance to norm adoption' over time, beginning with discourse, followed by the adoption of a global international legal regime (signalling the institutionalisation of the norm) and leading toward with the internalisation of the relevant principles. ${ }^{33}$ Risse and Sikkink, for instance, did 'not suggest that the causal arrows always point in one direction, as in "norms lead to change in interests", 34 but argued that resistance 'is rarely the end of the story' as '[e]ven instrumental adoption of human rights norms ... sets into motion a process of identity transformation'. ${ }^{35}$

There are various aspects of time that are relevant for analysing international criminal law, although it is beyond the scope of this article to address them. For instance, as others have discussed, the norm of international criminal justice might be presented as arising from a (teleological) accumulation of events progressing from certain spaces and times - from, say, the Treaty of Versailles (or trial of von Hagenbach, or earlier), to Nuremberg and Tokyo from 1945-1948, the ICTY's establishment, and Rome in $1998 .{ }^{36}$ Hinton argues that 'transitional justice time is a highly normative concept of past and present', ${ }^{37}$ that 'suggests a teleology of movement from a contaminated pre-state' of violence 'to a purified post-state of a modern liberal democratic order', with a tribunal 'serving as the mechanism of change'. ${ }^{38}$ The practice of international criminal tribunals raises specific temporal issues relating to jurisdiction as well as the time at which the trials take place. The 'authority' of international

\footnotetext{
33 Zimmermann, supra note 7, p. 5. See A. Betts and P. Orchard, 'Introduction: The Normative Institutionalization-Implementation Gap', in A. Betts and P. Orchard (eds.), Implementation and World Politics: How International Norms Change Practice (Oxford University Press, Oxford, 2014); J. G. Ruggie, 'What Makes the World Hang Together? Neo-utilitarianism and the Social Constructivist Challenge' 52(4) International Organization 855-885.

${ }^{34}$ T. Risse and K. Sikkink, 'The Socialization of International Human Rights Norms into Domestic Practices: Introduction', in T. Risse, S.C. Ropp and K. Sikkink (eds.), The Power of Human Rights: International Norms and Domestic Change (Cambridge University Press, Cambridge, 1999) pp. 1-38, p. 9; see also Goodman and Jinks, supra note 18; Koh, supra note 15.

${ }^{35}$ Risse and Sikkink, ibid., p. 10.

${ }^{36}$ See G. Simpson, Law, War \& Crime: War Crimes, Trials and the Reinvention of International Law (Polity, Cambridge, 2007), whereas the 'history of war crimes law can be comprehended as a series of undulations between recourse to the administration of local justice and grand gestures towards the international rule of law', p. 33; Buckley-Zistel supra note 8; Marieke De Hoon and Kjersti Lohne, 'Negotiating Justice at the ASP: From Crisis to Constructive Dialogue', EJIL: Talk!, 29 November 2016, <www.ejiltalk.org/negotiating-justice-at-theasp-from-crisis-to-constructive-dialogue/>, accessed 12 March 2018.

${ }^{37}$ A.L. Hinton, 'Transitional Justice Time: Uncle San, Aunty Yan, and outreach at the Khmer Rouge Tribunal' in Deborah Mayersen and Annie Pohlman (eds.), Genocide and Mass Atrocities in Asia: Legacies and Prevention, (Routledge, London, 2013) pp. 86-98, p. 87.

${ }^{38}$ Ibid., p. 94.
} 
criminal tribunals including the ICC with various stakeholders may also vary over time and in different political circumstances, including where trials occur long after the crimes. ${ }^{39}$

Further, international criminal law obligation may be cast as evolving through socialisation toward legal adoption (via ratification of the Rome Statute), the implementation of international criminal laws, and internalisation of these norms within domestic contexts. ${ }^{40}$ This article concentrates upon this latter aspect of time and international criminal law. Thus, a chronological account told today of Cambodia's progression from ratifying the Rome Statute, to adopting domestic international crimes legislation, to prosecuting international crimes at the ECCC replicates a familiar, linear, socialisation plot promoted since (arguably) the 1998 Rome Conference.

This focus upon how states progress from rejection toward the internalisation of norms is a product of the question such scholars are implicitly addressing: how can states comply with international laws? ${ }^{41}$ Posing this question casts states as the primary actors in diffusing and accepting norms, although constructivist scholars also recognise that that states consist of heterogeneous individuals, while transnational advocacy networks and civil society actors play an important role as 'norm entrepreneurs' (see below). Further, norm diffusion scholars have tended to focus on apparently 'ethically good' norms, such as the protection of human rights and prosecuting serious violations, ${ }^{42}$ so that resistance appears as a negative and potentially temporary aberration that may be overcome through additional socialisation. ${ }^{43}$

However, this perspective reduces the scope to explore how states might take alternative routes toward enforcing international (criminal) law, or why they might prioritise other goals. In contrast, a postcolonial perspective, for example, is 'acutely sensitive to the extent to which the past bears upon the present in ways that defy any attempt to package it away into neatly sequential analytical categories or 'stages'. ${ }^{44}$ That is, historic experiences can shape contemporary laws and legal enforcement in important, though often unpredictable and

\footnotetext{
${ }^{39}$ K.J. Alter, L.R. Helfer, M.R. Madsen, 'How Context Shapes the Authority of International Courts', 79(1) Law and Contemporary Problems (2016) 1-36; Leslie Vinjamuri, 'The International Criminal Court and the Paradox of Authority', 79(1) Law and Contemporary Problems (2016) 275-287.

${ }^{40}$ See Zimmerman, supra note 7, p. 6.

${ }^{41}$ E.g., see Goodman and Jinks, supra note 18.

42 J.T. Checkel, 'The Constructivist Turn in International Relations Theory' 50(2) World Politics (1998) 324-348, p. 339.

${ }^{43}$ See Risse and Sikkink, supra note 34, p. 10.

${ }^{44}$ Epstein, supra note 6, p. 307.
} 
dynamic ways. This article scrutinises this notion of temporal progress by investigating whether states in Southeast Asia have rejected, accepted, or adapted international criminal justice norms.

\subsection{Spatial Aspects}

Blomley has argued that law is inherently related to notions of space, including via legally designating boundaries, such as between the 'public' and 'private', as well as through the ways in which 'legal spaces are embedded in broader social and political claims'. ${ }^{45}$ Thus, in 'much the same way that law relies in various ways on claims concerning history, so it both defines and draws upon a complex range of geographies and spatial understandings'. ${ }^{46}$ 'Space', from this perspective, not only suggests a physical area or expanse, but is constructed within, and can constrain, social and power structures.

Analysing the spread of international criminal justice, especially through Rome Statute ratification across the world, involves a spatial awareness. On one hand, related advocacy may appear non-grounded, taking place through online press releases, petitions and social media campaigns. On the other, there is increasing recognition that international criminal justice comprises aspects of locality, perspective, or geography. ${ }^{47}$ Crimes are perpetrated, documented and prosecuted by courts in specific locations; court rooms divide participants from observers; ${ }^{48}$ perpetrators and survivors of international crimes (and those who are both $)^{49}$ reside in particular countries; national laws are made by state legislatures in capital cities; and protests take place in carefully selected locations. ${ }^{50}$ Colonial histories may also have enduring effects on legal systems, national identities, and economic contexts. ${ }^{51}$ Further,

\footnotetext{
${ }^{45}$ N. Blomley, Law, Space and the Geographies of Power (Guilford Press, New York, 1994), p. xi; L. Bennett and A. Layard, 'Legal Geography: Becoming Spatial Detectives', 9(7) Geography Compass (2015) 406-422.

${ }^{46}$ Blomley, supra note 45 , p. xi.

${ }^{47}$ E.g., Buckley-Zistel; Hughes; Riles, supra note 8; Leila Ullrich, 'Beyond the "Global-Local Divide": Local Intermediaries, Victims and the Justice Contestations of the International Criminal Court', Journal of International Criminal Justice (2016) 543-568; and see Tayyab Mahmud, 'Geography and International Law: Towards a Postcolonial Mapping', 5(2) Santa Clara Journal of International Law (2007) 525.

${ }^{48}$ See Buckley-Zistel, supra note 8, p. 19 in relation to the ECCC.

${ }^{49}$ R. Shaw and L. Waldorf, 'Introduction: Localizing Transitional Justice', in R. Shaw, L. Waldorf and P. Hazan (eds.), Localizing Transitional Justice: Interventions and Priorities after Mass Violence (Stanford University Press, Stanford, 2010), pp. 3-26, p. 8.

${ }^{50} \mathrm{~J}$. Suh, The Politics of Transitional Justice in Post-Suharto Indonesia, (Ohio State University, Columbus, 2012), p. 125.

${ }^{51}$ Mahmud, supra note 47.
} 
the principle of complementarity rests upon a distinction between domestic territorial jurisdictions and the ICC.

Beyond such physical conceptions of space, a spatial awareness recognises that 'even the initial characterization of [an] issue must take place from the situated viewpoint of one system or another'. ${ }^{52}$ Different actors may take different positions as to whether a given matter pertains to international criminal justice (or, for instance, human rights, development, or conflict resolution) depending on their background, training and location. For example, this author's international criminal law education influenced the choice to approach this topic with reference to international criminal justice and particular international relations frameworks.

International criminal law scholarship often identifies different 'levels, ${ }^{53}$ of engagement with international criminal justice, including by distinguishing between 'international', 'regional', and 'local' ideas and actors. Constructivist scholarship has long demonstrated the important role of transnational advocacy networks and 'norm entrepreneurs' in diffusing norms. ${ }^{54}$ Acharya has drawn attention to the particular influence of 'credible local actors' and 'the divide between transnational actors who operate across continents and time zones and local actors ... who are situated within single time zones and marginalized locations' ${ }^{55}$

These local/international divisions can highlight the importance of different perspectives and experiences. For instance, postcolonial and anthropology scholars have demonstrated how international criminal justice mechanisms can fail to integrate the concerns of those most affected by them and may even cause harm. ${ }^{56}$ Some argue that 'local' customary approaches

\footnotetext{
${ }^{52}$ K. Knop, R. Michaels and A. Riles, 'From Multiculturalism to Technique: Feminism, Culture, and the Conflict of Laws Style', 64 Stanford Law Review (2012) 588-656, p. 634, emphasis added; see Hughes; Riles, supra note 8.

${ }^{53}$ For a critique regarding human rights, see M. Goodale, 'Ethical Theory as Social Practice', 108(1) American Anthropologist (2006) 25-37; A. Björkdahl et al, 'Introduction: Peacebuilding through the Lens of Friction', in A. Björkdahl et al (eds.), Peacebuilding and Friction: Global and Local Encounters in Post Conflict-Societies (Routledge, Milton Park, 2016) pp. 1-16.

${ }^{54}$ M.E. Keck and K. Sikkink, Activists Beyond Borders: Advocacy Networks in International Politics (Cornell University Press, Cambridge, 1998).

55 A. Acharya, Local and Transnational Civil Society as Agents of Norm Diffusion, $<$ amitavacharya.com/sites/default/files/Local\%20and\%20Transnational\%20Civil\%20Society\%20as\%20Agents \%20of\%20Norm\%20Diffusion.pdf $>$, accessed 12 March 2018.

${ }^{56}$ See contributions in Shaw, Waldorf and Hazan, supra note 8; and Hinton, supra note 9; E. Drexler, 'The Failure of International Justice in East Timor and Indonesia' in A.L. Hinton (ed.), Transitional Justice: Global Mechanisms and Local Realities after Genocide and Mass Violence (Rutgers University Press, New Brunswick,
} 
to dispute resolution and reconciliation may offer advantages including flexibility and legitimacy and still provide accountability for perpetrators. ${ }^{57}$

However, this 'local turn' ${ }^{58}$ has been criticised for 'romanticising the local', ${ }^{59}$ risking the marginalisation of some groups such as women, ${ }^{60}$ and failing to recognise how global and local spheres are 'intertwined'. ${ }^{61}$ Focusing on 'global' or 'local' solutions may 'reify the "global" and the "local" as self-evident categories for making sense of the ICC's relationship with affected communities'. ${ }^{62}$ These classifications can establish 'an implicit dichotomy between good global/universal norms and bad regional/local norms', ${ }^{63}$ which are expected to 'clash' ${ }^{64}$ Some scholars have pointed out that, in practice, the boundaries between actors and norms blur and shift rather than being 'fenced off by some form of boundary' ${ }^{65}$ Indeed, 'the things we call "global" are often circulating locals', ${ }^{66}$ while 'if the local is constructed over space and time, so is the global'. ${ }^{67}$ Further, actors and ideas labelled state, non-state, local, or global, can engage and intersect, rather than clash, even if this interaction involves friction. ${ }^{68}$

This suggests that spatial designations such as local or global may be better understood as dynamic and mutually reinforcing social constructions than firm categories. The helpfulness of this particular spatial characterisation for considering approaches toward international criminal justice in Southeast Asia is explored below.

\subsection{Directional Aspects}

2010) pp. 49-66; K.M. Clarke, Fictions of justice: the International criminal court and the challenges of legal pluralism in sub-Saharan Africa (Cambridge University Press, Cambridge, 2009).

57 See Shaw, Waldorf and Hazan, supra note 49, p. 14.

${ }^{58}$ R. Mac Ginty and O.P. Richmond, 'The Local Turn in Peace Building: a critical agenda for peace', 34(5) Third World Quarterly (2013) 763-783.

${ }^{59}$ Björkdahl et al, supra note 53, p. 10, see Mac Ginty and Richmond, ibid., p. 765.

${ }^{60}$ Shaw, Waldorf and Hazan, supra note 49, p. 16.

${ }^{61}$ Björkdahl et al, supra note 53, p. 10; see Buckley-Zistel, supra note 8, p. 18.

${ }^{62}$ Ullrich, supra note 47, p. 7.

${ }^{63}$ Acharya, supra note 22, p. 185.

${ }^{64}$ Shaw, Waldorf and Hazan, supra note 49, p. 5.

${ }^{65}$ Buckley-Zistel, supra note 8, p. 22.

${ }^{66}$ S. Engle Merry, 'Transnational Human Rights and Local Activism: Mapping the Middle',108(1) American Anthropologist (2006) 38-51, p. 40, see Björkdahl et al, supra note 53, p. 4.

${ }^{67}$ Buckley-Zistel, supra note 8, p. 24.

${ }^{68}$ See A. Lowenhaupt Tsing, Friction: An Ethnography of Global Connection (Princeton University Press, Princeton, 2005); Shaw, Waldorf and Hazan, supra note 49, p. 5. 
Constructivist approaches often include assumptions about the movement of ideas across both time and space, or directionality - especially that 'global' influence ${ }^{69}$ flows toward the 'local'. Local events can 'become international', ${ }^{70}$ for instance through the ICC launching an investigation into an incident, perhaps encouraged by transnational advocacy networks.

However, directional normative change is implied even where transnational advocacy networks encourage the transmission of international norms to recipient states both 'from above' and 'from below'. ${ }^{71}$ It is relatively rare to consider how local actors and concepts, especially in developing states, contribute toward international norm-making processes, although Acharya's localisation framework provides an important contribution by emphasising local agency. ${ }^{72}$ Still less common is an investigation of how structural and power dynamics affect - and are affected by - the agency of such actors.

The concept of directionality indicates that 'questions about norm diffusion in world politics are not simply about whether and how ideas matter, but also which and whose ideas matter'. ${ }^{73}$ Scholars and civil society actors often consider how international organisations and states can best disseminate the international norms represented by the Rome Statute to recipient states and local communities, albeit potentially with the assistance of credible local mediators - such as national members of the Coalition for the International Criminal Court (CICC). ${ }^{74}$ The influence of international actors and legal regimes, including ICC outreach and broad notions of complementarity, ${ }^{75}$ may be emphasised over the agency and alternative approaches of others. This may manifest in a preference for domestic international crimes legislation to be modelled as closely upon the Rome Statute as possible, ${ }^{76}$ or in advocating for international criminal justice responses to the commission of international crimes, such as

\footnotetext{
${ }^{69}$ In this article, 'influence' suggests a 'causal relation' between two or more actors or events, recognising that influence 'is not something that is either had or not had, it comes in degrees': M. Glasius, Foreign Policy on Human Rights: Its Influence on Indonesia under Soeharto (Hart, Oxford, 1999), p. 15.

${ }^{70}$ Riles, supra note 8, p. 41.

${ }^{71}$ Risse and Sikkink, supra note 34 , p. 18.

${ }^{72}$ For exceptions, see Merry in relation to global norms representing 'circulating locals', supra note 66, p. 40; A. Acharya, 'Norm Subsidiarity and Regional Orders: Sovereignty, Regionalism, and Rule-Making in the Third World', 55(1) International Studies Quarterly (2011) 95-123.

${ }^{73}$ Acharya, supra note 9, p. 239.

${ }^{74}$ M.B. Schroeder and A. Tiemessen, 'Transnational Advocacy and Accountability: From Declarations of AntiImpunity to Implementing the Rome Statute', in A. Betts and P. Orchard (eds.), Implementation and World Politics: How International Norms Change Practice (Oxford University Press, Oxford, 2014) pp. 50-67.

${ }^{75}$ E.g., L. Moffett, 'Elaborating Justice for Victims at the International Criminal Court: Beyond Rhetoric and The Hague', 13(2) Journal of International Criminal Justice (2015) 281-311.

${ }^{76}$ See C. Stahn, 'Justice civilisatrice? The ICC, post-colonial theory, and faces of "the local", in C. De Vos, S. Kendall and C. Stahn (eds.), Contested Justice: The Politics and Practice of International Criminal Court Interventions (Cambridge University Press, Cambridge, 2015) pp. 46-84.
} 
via the ICC or internationalised tribunals. This article considers how actors within and outside Southeast Asia have sought to develop (or have resisted) laws and mechanisms for prosecuting international crimes over time and across different spaces.

\section{Time, Space and Direction and International Criminal Justice}

In summary, many norm diffusion theories suggest that civil society and state actors can encourage states to internalise a normalised understanding of international criminal justice that centres upon the Rome Statute framework, even where conduct might be prosecuted domestically. This process of acceptance is expected to occur over time through engagement between spatially differentiated actors and ideas, which encourages the norm of international criminal justice to flow (from The Hague) in the direction of receiving locals. However, an analysis of national legislation, government statements, NGO reports, and interviews in Southeast Asia challenges assumptions concerning the temporal progression, spatial divisions, and direction of the diffusion of international criminal justice.

\subsection{Time: Interrupted and non-linear engagement.}

Constructivists notoriously struggle to explain the disjuncture between states' adoption of international instruments and laws and failure to enforce them (the 'action-identity' gap, ${ }^{77}$ 'institutionalization-implementation' gap ${ }^{78}$ or 'decoupling, $\left.{ }^{79}\right)$. Such inconsistencies challenge accounts that anticipate progression from ratification toward internalisation.

For instance, the states in Southeast Asia that have not ratified the Rome Statute, including Indonesia and Vietnam, can still have laws for prosecuting international crimes, ${ }^{80}$ or, like Malaysia, might have taken tangible steps toward joining the ICC, ${ }^{81}$ or pursue non-judicial responses via official and civil society bodies. ${ }^{82}$ States with domestic international crimes legislation like Cambodia, Indonesia, the Philippines, or Vietnam are not necessarily progressing from a position of rejecting international criminal justice toward acceptance,

\footnotetext{
${ }^{77}$ M. Davies, 'ASEAN and human rights norms: constructivism, rational choice, and the action-identity gap', 13(2) International Relations of the Asia-Pacific (2013) 207-231.

${ }^{78}$ Betts and Orchard, supra note 33.

${ }^{79}$ Goodman and Jinks, supra note 18.

${ }^{80}$ Law 26/2000; Vietnam Code, supra note 12.

${ }^{81}$ Malaysia completed the domestic prerequisites to join the ICC by obtaining the approval of the Malaysian Cabinet in 2011 but has not ratified the Rome Statute.

${ }^{82}$ Including investigations by National Human Rights Institutions or Commissions.
} 
either. Such legislation may narrow, as well as broaden, the potential scope for convictions relative to crimes included in the Rome Statute. For example, the Philippines' international crimes legislation addresses persecution on the basis of sexual orientation, whereas Indonesia's only covers crimes against humanity and genocide (not war crimes). ${ }^{83}$

These laws do not necessarily lead to fairer (or any) trials, the conviction of perpetrators, or reparations for victims. Nor is it obvious that they prevent the reoccurrence of human rights violations that might be considered international crimes. ${ }^{84}$ The ECCC and SPs are internationalised institutions with limited temporal, personal, and subject-matter jurisdiction, while Indonesia has also prosecuted international crimes under its Law 26/2000 (though all convictions were overturned). Each of these mechanisms has been criticised for involving selective prosecutions, restricted resources, and fair trial concerns, ${ }^{85}$ despite arguably representing the implementation of international crimes laws. In other words, the reconstruction of international norms is not necessarily 'progressive" ${ }^{86}$ - at least from the perspective of those interested in 'ending impunity'. Yet across the region, civil society and some state actors have also supported the prosecution of international crimes (see below).

In reality, different administrations take varied positions at different times toward prosecuting international crimes, in dialogue with various actors. For example, in 2016, debates about amending Indonesia's Law 26/2000 coincided with proposals to incorporate international crimes into Indonesia's revised Criminal Code (with prospective operation), advocacy about reforming the military Criminal Code, and a national symposium to review past human rights violations. Many of these debates persisted from the previous President Yudhoyono's administration, while the symposium was a relatively newer development that drew on current President Jokowi's presidential campaign. Moreover, civil society and victims' groups present evolving and sometimes competing demands, whether for truth and

\footnotetext{
${ }^{83}$ Supra note 12.

${ }^{84}$ E.g., in the Philippines, though see ICC, 'Statement of the Prosecutor of the International Criminal Court, Mrs Fatou Bensouda, on opening Preliminary Examinations into the situations in the Philippines and in Venezuela', 8 February 2018, <www.icc-cpi.int/Pages/item.aspx?name=180208-otp-stat $>$, accessed 12 March 2018.

${ }^{85}$ E.g., International Center for Transitional Justice (ICTJ) and KontraS, Derailed: Transitional Justice in Indonesia since the Fall of Soeharto, 2011, <www.ictj.org/publication/derailed-transitional-justice-indonesiafall-soeharto-report>, accessed 12 March 2018; Drexler, supra note 56; J Ciorciari and A Heindel, Hybrid Justice: The Extraordinary Chambers in the Courts of Cambodia (Law, Meaning, and Violence) (University of Michigan Press, Ann Arbor, 2014).

${ }^{86}$ For instance, Acharya's localisation framework is offered as 'an evolutionary or "everyday" form of progressive norm diffusion', supra note 9 , p. 252.
} 
reconciliation commissions, reparations, or prosecutions. In the Philippines, domestic legislation prohibiting international crimes (the IHL Act) ${ }^{87}$ may be amended so as to narrow the range of war crimes that the law currently addresses in a non-international armed conflict. $^{88}$

This lends support to Zimmerman's insight that debates and choices about international and local norms recur as new problems arise (including new incidents of violence), when laws are proposed, as legislation is passed, and again when efforts are made to enforce these instruments. ${ }^{89}$ Each decision can be revisited or run in parallel as alternative responses to international crimes are pursued in different contexts. The harms victims experience can also change, including in the case of inter-generational trauma (as is also becoming evident in Cambodia). ${ }^{90}$

All of these debates might intersect, but they also invite distinct legal responses that develop or reverse previous initiatives, and are built upon in turn. Rather than representing the outcome of a period of socialisation, institutionalisation, and implementation of treaty norms, responses to international crimes represent dynamic and continuing processes.

\subsection{Space: tensions between different ideas and actors}

International states and organisations, authorities within Southeast Asia and civil society representatives often debate international criminal justice with reference to principles considered relevant for the particular geographic area. The suggestion that such reframing and adaptation is important, especially when undertaken by 'local' actors, represents a significant contribution of Acharya's localisation framework. ${ }^{91}$ Such 'credible local actors' may include politicians and members of statutory agencies and National Human Rights Institutions, lawyers and judges, NGO representatives (especially human rights activists and

\footnotetext{
${ }^{87}$ Ibid.

${ }^{88}$ House Bill 2834, An Act Amending Republic Act 9851, August 2016, pending with Committee on Justice.

${ }^{89}$ L. Zimmermann, Global Norms with a Local Face: Rule-of-Law Promotion and Norm Translation (Cambridge University Press, Cambridge, 2017); Betts and Orchard, supra note 33, p. 4.

${ }^{90}$ N.P. Field, S. Muong, V. Sochanvimean, 'Parental Styles in the Intergenerational Transmission of Trauma Stemming From the Khmer Rouge Regime in Cambodia', 83(4) American Journal of Orthopsychiatry (2013) 483-494.

${ }^{91}$ Acharya, supra note 9.
} 
victims' representatives), and media. However, applying spatial boundaries to the 'local' and 'international' can be complicated.

First, characterising a particular group or individual as 'local' or 'global/international' is subjective. ${ }^{92}$ National NGO's may appear 'local' by comparison to the UN or a Hague-based international criminal law regime or have close relations with state agencies. However, such groups may be far removed from stakeholder communities, especially in remote areas.

KontraS in Indonesia attempts to combat this via internship programmes involving young people from remote locations, while Karapatan and other organisations in the Philippines consult closely with community leaders. Still, NGO representatives might consider themselves 'local', ${ }^{93}$ but be subject to 'international donor imperatives that delimit the power that their own vernacular knowledge forms can have in shaping solutions'.${ }^{94}$ For example, when Cambodian NGOs lost funding to represent the participation of civil parties in ECCC proceedings. ${ }^{95}$ Further, attempts to engage directly with international criminal law institutions must still abide by their procedures: victim participation in trials, reparations and outreach processes at the ECCC are subject to the ECCC's rules, ${ }^{96}$ while Article 15 communications inviting the ICC Prosecutor to investigate events in Cambodia involved legal advice and submissions. ${ }^{97}$ In these circumstances, whether a group appears 'local' or 'international' may depend on the observer's perspective.

Second, as a result of this subjectivity, defining a group or an idea as 'local' is practically difficult. There is no unified 'local', 'Western', 'international society' or 'global' perspective on prosecuting international crimes in Southeast Asia. Actors also often fail to clearly represent either category. EU experts are seconded to 'local' NGOs to work alongside

\footnotetext{
92 See Ullrich, supra note 47; Björkdahl et al, supra note 53; Sally Engle Merry, Human Rights \& Gender Violence: Translating International Law Into Local Justice (University of Chicago Press, Chicago, 2006), 214; Buckley-Zistel, supra note 8.

${ }^{93}$ Ullrich, supra note 47, p. 7.

${ }^{94}$ Clarke, supra note 56, p. 135.

95 Alice Cuddy, 'Victim lawyers stung by cuts', The Phnom Penh Post, 11 May 2015 $<$ www.phnompenhpost.com/national/victim-lawyers-stung-cuts>, accessed 12 March 2018.

${ }^{96}$ See Law to Amend the 2001 Law on the Establishment of the Extraordinary Chambers in the Courts of Cambodia, 27 October 2004; see Internal Rules Rev.9, 16 January 2015.

${ }^{97}$ E.g., Global Diligence, Communication Under Article 15 of the Rome Statute of the International Criminal Court The Commission of Crimes Against Humanity in Cambodia July 2002 to Present, 2014, $<$ www.fidh.org/International-Federation-for-Human-Rights/asia/cambodia/16176-cambodia-icc-preliminaryexamination-requested-into-crimes-stemming-from>, accessed 12 March 2018.
} 
'locals' and international expatriates in Cambodia. ${ }^{98}$ Cambodian group DC-Cam has collaborated with the Network for Human Rights Documentation-Burma (ND-Burma). ${ }^{99}$ Myanmar NGOs operate from the Thailand border. Influential diaspora communities participate in the ECCC trials as civil parties ${ }^{100}$ or may organise events such as the International Peoples Tribunal (IPT) 1965 - a 'people's tribunal' that considered violence committed in 1965 in Indonesia. In this way, 'local and global are inherently related to each other rather than mutually exclusive'. ${ }^{101}$

Third, there is complexity involved in determining which ideas and practices are local as opposed to global (or 'external'). ${ }^{102}$ The array of legal and traditional rules of engagement and conflict resolution mechanisms in Southeast Asia ${ }^{103}$ might only be grouped as 'local' when compared to the Rome Statute. For example, the practice in Timor-Leste of nahe biti bo 'ot (spreading the large mat) and lisan ${ }^{104}$ are different from the 'islah' procedure in parts of Indonesia. ${ }^{105}$ Various procedures can be labelled 'local' for their contrast to the 'non-local' international criminal justice norm. Thus, local and global principles are defined with reference to the other; they are mutually constitutive.

Moreover, apparently 'local' norms may arise from complex sources. For instance, many Southeast Asian states have sought to protect their sovereignty from the exercise of ICC jurisdiction. This concern, shared by states in other regions, ${ }^{106}$ may be perceived as

\footnotetext{
${ }^{98}$ European Union, European Development Cooperation Strategy for Cambodia 2014-2018, November 2014, $<$ eeas.europa.eu/delegations/cambodia/documents/publications/2015/2014_eujoint_strategy_en.pdf>, accessed 12 March 2018.

${ }^{99}$ International Centre for Transitional Justice, 'DC-Cam to Help Burma Record Rights Abuses', 8 May 2013, $<$ www.ictj.org/news/dc-cam-help-burma-record-rights-abuses>, accessed 12 March 2018.

${ }^{100}$ E.g., N. Katjasungkana, 1965 Tribunal Hearings: Welcome statement by Nursyahbani Katjasungkana, general coordinator Foundation IPT 1965, <www.tribunal1965.org/en/1965-tribunal-hearings-welcome-statement-bynursyahbani-katjasungkana-general-coordinator-foundation-ipt-1965/>, accessed 12 March 2018.

${ }^{101}$ Buckley-Zistel, supra note 8, p. 25.

102 Acharya, supra note 9.

${ }^{103}$ See Hinton, supra note 9; Shaw, Waldorf and Hazan, supra note 8; Drexler, supra note 56; F. Agus, Traditional laws of war in Indonesia: published for 50th anniversary of Geneva Conventions 1949 (Centre for Study on Humanitarian Law, Trisakti University and International Committee of the Red Cross, Jakarta, 1999).

${ }^{104}$ L. Vieira, 'The CAVR and the 2006 Displacement Crisis in Timor-Leste: Reflections on Truth-Telling, Dialogue, and Durable Solutions', ICTJ, Brookings-LSE, July 2012, <www.ictj.org/sites/default/files/ICTJBrookings-Displacement-Truth-Telling-Timor-Leste-CaseStudy-2012-English.pdf>, accessed 12 March 2018, see also Drexler, supra note 56.

${ }^{105}$ Kimura Ehito, 'The Struggle for Justice and Reconciliation in Post-Suharto Indonesia' (2015) 4(1) Southeast Asian Studies 73-93.

${ }^{106}$ ICC, Summary records of the plenary meetings and of the meetings of the Committee of the Whole (Volume II), United Nations Diplomatic Conference of Plenipotentiaries on the Establishment of an International Criminal Court, 15 June - 17 July 1998, e.g., United States, pp. 152, 361; Nigeria including regarding the African Union,
} 
conflicting with the norms of international criminal justice. ${ }^{107}$ NGOs have responded to this lack of 'fit' through reframing the principle of complementarity as being consistent with state sovereignty, including in Indonesia. ${ }^{108}$ In the Philippines, NGOs suggested that adopting international crimes laws and ratifying the Rome Statute would enhance the country's historically important appreciation for human rights. ${ }^{109}$ Neither human rights nor sovereignty are only 'local' norms. ${ }^{110}$ Yet, the tendency of actors in Indonesia or the Philippines to choose to draw upon these principles derived from experiences arising within those 'spaces'.

Fourth, power and material contexts intersect with spatial categories. Colonial histories have generated particular experiences of violence and impunity within states whose boundaries were defined during occupation. ${ }^{111}$ Historic conflicts and economic conditions in certain places might increase the relative importance of international assistance, for example, as in Cambodia and Timor-Leste, which both became sites for international crimes trials. International actors were implicated in both conflicts and their recovery efforts, meaning that the prosecutions cannot only be explained with reference to domestic conditions.

Finally, it is difficult to define some actors in Southeast Asia as 'local' or 'international', but this does not mean that everyone has access to either characterisation, all the time. National laws are adopted by geographically defined states, within which different individuals have more or less connection to sites of violence and actors' mobility is uneven. Some individuals move between provinces and across the world, as where Myanmar nationals travel to South Africa to discuss truth and reconciliation options, Cambodian NGO representatives attend the ICC Assembly of States Parties (ASP), and activists research and communicate online. ${ }^{112}$ However, even if spatial divisions are social constructs, they can still constrain. In other words, access to global forums such as the ASP may be relatively restricted for many, even as online networks provide additional avenues for advocacy. Rather than dividing actors and

p. 111; Mexico, p. 107; China, pp. 75, 123-124; Pakistan, pp. 78, 127, 173, and including regarding Non-Aligned Movement states, p. 189; India, p. 86.

${ }^{107}$ Findlay; Kapur, supra note 31, pp. 4-5; Toon, supra note 29, p. 22.

${ }^{108}$ E.g., Y.K.D. Nafi, Ratification of Rome Statute by Indonesia: A Commitment to Human Rights or a Threat to Sovereignty? (Universiteit van Amsterdam, Amsterdam, 2014) <dare.uva.nl/cgi/arno/show.cgi?fid=544822>, accessed 12 March 2018.

${ }^{109}$ Philippine Coalition for the International Criminal Court (PCICC), For Hope \& Human Dignity: A Primer on the International Criminal Court for the Security Sector (2008), copy on file with author.

${ }^{110}$ Acharya, supra note 72.

${ }^{111}$ Mahmud, supra note 47, p. 545.

${ }^{112}$ Buckley-Zistel, supra note 8, p. 28. 
ideas into bounded categories, it is useful to consider space as being socially constructed and constitutive.

\subsection{Direction and Agency}

Activists and victims' representatives, lawyers, military leaders, journalists, politicians and other state and non-state actors based - and sometimes moving - around the world engage in debates concerning international criminal justice within Southeast Asia, suggesting that ideas flow in multiple directions. International states, organisations, and legal instruments have been influential. For example, though belatedly, a UN-appointed Group of Experts drew attention to crimes committed during Democratic Kampuchea (DK), and the UN ${ }^{113}$ and international NGOs advocated for international control over DK trials. ${ }^{114}$ Similarly, the UN arranged the establishment of the SPs and it is unlikely that Indonesia would have adopted Law 26/2000 were it not for the international attention directed toward violence in East Timor. ${ }^{115}$

However, until the early 2000s there was little international appetite for the Security Council to establish mechanisms to address crimes in Cambodia or East Timor. This occurred within the context of Cold War politics, that led for example to a Khmer Rouge coalition retaining Cambodia's seat at the UN until 1991, despite emerging evidence of atrocities, while China had emerged 'as the Pol Pot regime's main external sponsor...' 116 The US contributed to the establishment of the ECCC, but also asked Southeast Asian states to sign Bilateral Immunity Agreements, to ensure that nationals of either state would not be delivered to the ICC.

\footnotetext{
${ }^{113}$ Situation of human rights in Cambodia: Report of the Secretary-General (A/54/353), 20 September 1999, p. 8; United Nations General Assembly, Resolution adopted by the General Assembly on the report of the Third Committee, 57/228, Khmer Rouge trials (A/RES/57/228), 22 May 2003; Secretary General, Report of the Secretary-General on the Khmer Rouge trials (A/57/769), 31 March 2003, p. 5.

${ }^{114}$ Human Rights Watch, Serious Flaws: Why the U.N. General Assembly Should Require Changes to the Draft Khmer Rouge Tribunal Agreement, 2003, <www.hrw.org/legacy/backgrounder/asia/cambodia043003-bck.pdf\$, accessed 12 March 2018, p. 3; Amnesty International, Kingdom of Cambodia: Amnesty International's position and concerns regarding the proposed "Khmer Rouge" tribunal, 2003, <www.refworld.org/pdfid/3f12fb834.pdf>, accessed 12 March 2018.

${ }^{115}$ ICTJ and KontraS, supra note 85.

116 John Ciorciari and Anne Heindel, Hybrid Justice: The Extraordinary Chambers in the Courts of Cambodia (Law, Meaning, and Violence) (University of Michigan Press, Ann Arbor, 2014), 15; Andrew Mertha, Brothers in Arms: Chinese Aid to the Khmer Rouge, 1975-1979 (Cornell University Press, Ithaca, 2014); B. Kiernan, Genocide and Resistance in Southeast Asia: Justice in Cambodia \& East Timor (Transaction Publishers, New Brunswick, 2008); T. Fawthrop and H. Jarvis, Getting Away with Genocide?: Cambodia's Long Struggle Against the Khmer Rouge (UNSW Press, Sydney, 2005).
} 
International states take diverse and changing positions towards international criminal justice in Southeast Asia.

International institutions have also shaped Southeast Asian states' approaches to prosecuting international crimes. The ICC has not yet pursued investigations in the region, but has announced a preliminary examination of alleged crimes in the Philippines. ${ }^{117}$ The former President of the Court, Justice Song, was a regular visitor to Southeast Asia to promote Rome Statute ratification. ${ }^{118}$ The Universal Periodic Review (UPR) process ${ }^{119}$ and the ICC provide additional forums for critique and civil society actors in Cambodia and the Philippines have submitted Article 15 communications inviting the ICC Prosecutor to investigate crimes in each country.

Regional states' domestic international crimes legislation is predominantly modelled upon the Rome Statute, though with minor departures. ${ }^{120}$ Civil society actors refer to the Statute when advocating for responses toward human rights violations in Southeast Asia and even for broader purposes such as responding to gender-based violence - for example, in the Philippines. ${ }^{121}$ This is understandable - the Rome Statute provides a convenient model for international crimes legislation and is now a relatively strong international treaty regime with 124 states parties. Still, this focus on the Statute has consequences.

International crimes may require additional evidence than 'ordinary' criminal offences - for example, crimes against humanity must be widespread or systematic, and genocide requires proving specific intent. ${ }^{122}$ States in Southeast Asia have not adopted the ICC's Elements of Crimes into domestic legislation, or modified domestic criminal procedures or modes of

\footnotetext{
${ }^{117}$ ICC, supra note 84.

118 CICC, Asia-Pacific Update, Issue $\quad$ 5, $\quad$ May $\quad 2010$, $<$ www.iccnow.org/documents/Asia_Newsletter_Issue5_final.pdf $>$, accessed 12 March 2018.

${ }^{119}$ E.g., Human Rights Council, Report of the Working Group on the Universal Periodic Review: Myanmar, (A/HRC/31/13), 23 December 2015, paras. 143.80-143.82, 145.1-145.5, 145.28; Human Rights Council, Report of the Working Group on the Universal Periodic Review: Indonesia (A/HRC/8/23), 14 May 2008, paras. 41, 65, 73; Human Rights Council, Report of the Working Group on the Universal Periodic Review: Indonesia (A/HRC/21/7), 5 July 2012, paras. 108.88, 108.90, 108.91, 108.119.

${ }^{120}$ With the exception of Vietnam, where legislation was adopted prior to the Rome Conference.

${ }^{121}$ PCICC, Day of Justice 2012: Women \& human rights advocates talk gender-just reparations for Lubanga victims, 20 July 2012, <pcicc.wordpress.com/2012/07/20/day-of-justice-2012-women-human-rights-advocatestalk-gender-just-reparations-for-lubanga-victims/>, accessed 12 March 2018.

122 See R. Cryer, Prosecuting International Crimes: Selectivity and the International Criminal Law Regime (Cambridge University Press, Cambridge, 2005), p. 175.
} 
liability in order to address international crimes. ${ }^{123}$ In consequence, prosecuting international crimes may be even more difficult than pursuing other criminal charges, Constitutional remedies or non-criminal responses.

International criminal justice has been promoted as a potential mechanism for resolving serious human rights violations - for instance by political and civil society actors arguing that forced transfers and evictions in Cambodia amount to international crimes. ${ }^{124}$ Yet it is not clear that Southeast Asian states with more developed international criminal law frameworks are more likely to resolve (or avoid) human rights violations that may or may not be considered international crimes. Even though there have been a relatively large number of relevant trials in the broader Asia-Pacific region, ${ }^{125}$ and atrocities have arguably declined, ${ }^{126}$ rather than a 'justice cascade', ${ }^{127}$ human rights repression may even be increasing in some areas. ${ }^{128}$ If international crimes are not proven or convictions are overturned (as in the case of Indonesia's Law 26/2000 trials), perpetrators of violence escape justice and victims may be left without remedy.

A focus on the Rome Statute may restrict the exploration of alternative responses to international crimes and other violent incidents. ${ }^{129}$ This may occur even in non-party states through stifling creativity or because justice advocates focus their resources on the ICC to the detriment of other projects. Where the ICC is unlikely to have jurisdiction, it is arguably even more important to develop domestic criminal, or alternative, frameworks for responding to violence. In fact, this has occurred in some Southeast Asian states such as Indonesia, with its Law 26/2000, public hearings arranged by NGOs during the 2013 'Year of Truth', and the

\footnotetext{
${ }^{123}$ Although sections 8-12 of the Philippines IHL Act address 'some principles of criminal liability' including superior responsibility, supra note 12.

${ }^{124}$ E.g., Global Diligence, supra note 97.

12532 per cent of international human rights prosecutions (which includes trials by 'internationalised' tribunals) between 1970 and 2009 concerned Asia-Pacific residents. This rate compared with 37 per cent of African accused and 30 per cent European accused, see L.A. Payne and K. Sikkink, 'Transitional Justice in the Asia-Pacific: Comparative and Theoretical Perspectives', in R. Jeffery and H.J. Kim (eds.), Transitional Justice in the AsiaPacific (Cambridge University Press, Cambridge, 2014) pp. 33-60, p. 38.

${ }^{126}$ A.J. Bellamy, 'The other Asian miracle? The decline of mass atrocities in East Asia', 26(1) Global Change, Peace \& Security (2014) 1-19.

${ }^{127}$ K. Sikkink, The Justice Cascade: How Human Rights Prosecutions Are Changing World Politics, (W W Norton \& Company, New York, 2011).

${ }^{128}$ Open Society Justice Initiative, Performance and Perception: The Impact of the Extraordinary Chambers in the Court of Cambodia, 2016, <www.opensocietyfoundations.org/reports/performance-and-perception-impactextraordinary-chambers-court-cambodia $>$, accessed 12 March 2018;

${ }^{129}$ Stahn, supra note 76, p. 58; S. Nouwen and W. Werner, 'Monopolizing Global Justice: International Criminal Law as Challenge to Human Diversity', 13(1) Journal of International Criminal Justice (2014) 157-176; Mark A. Drumbl, Atrocity, punishment, and international law (Cambridge University Press, Cambridge, 2007).
} 
2016 national symposium, and in Cambodia with the development of 'Women's Hearings' where participants to shared experiences of sexual violence during DK. ${ }^{130}$

Actors based within Southeast Asia have influenced the laws and mechanisms relating to international criminal justice. This includes official representatives, although states do not represent homogenous positions. Parliamentarians in the Philippines advocated for the passage of the Philippines IHL Act ${ }^{131}$ and Rome Statute ratification, despite the unwillingness of the executive government under Arroyo. ${ }^{132}$

In contrast to the public comments made by the African Union (AU), often to oppose the ICC, ASEAN provides only limited scope for overtly discussing international criminal justice. ${ }^{133}$ While there is no consistent regional position, Cambodia secured significant influence over the ECCC, Indonesia implemented Law 26/2000 and prefers to develop an 'Indonesian way' to resolve past human rights abuses, ${ }^{134}$ and the Philippines adopted domestic international crimes legislation prior to ratifying the Rome Statute. Though modelled on the Rome Statute, domestic legislation across the region also retains some distinctions. ${ }^{135}$

Civil society actors have also contributed to legislative and policy changes within states, even if international funding and pressure has been important. Groups such as DC-Cam and NDBurma have documented crimes, while across the region NHRIs and human rights NGOs monitor and report violations, ${ }^{136}$ not only via international processes, but also via social and traditional media. For instance, activists in Myanmar have brought legal cases while also publicising reports of international crimes. ${ }^{137}$ Where international crimes mechanisms have

\footnotetext{
${ }^{130}$ B. Ye, 'Transitional Justice Through the Cambodian Women's Hearings', 5 Cambodia Law and Policy Journal (2014) 23-38.

131 Supra note 12.

${ }^{132}$ See House Bill No. 6298, 12 August 2003, Republic of the Philippines; Soliman M Santos Jr, 'Correspondents' Reports: The Philippines' (2003) 6 Yearbook of International Humanitarian Law 561-578, p. 571.

${ }^{133}$ Freeland, supra note 30.

${ }^{134}$ A. Wahyuningroem, 'Justice denied?', 125 Inside Indonesia (2016), <www.insideindonesia.org/justicedenied>, accessed 12 March 2018.

${ }^{135}$ For instance, the Philippines IHL Act includes persecution on the grounds of sexual orientation and Cambodia's Criminal Code extends liability for international crimes to corporate perpetrators, supra note 12.

${ }^{136}$ E.g., Karapatan Alliance for the Advancement of People's Rights, 2015 Karapatan Year-end Report on the Human Rights Situation in the Philippines, July 2016, <karapatan.org/2015+Human+Rights+Report>, accessed 12 March 2018.

${ }^{137}$ E.g., Kachin Women's Association Thailand and Legal Aid Network, Justice Delayed, Justice Denied: Seeking Truth about Sexual Violence and War Crime Case in Burma, January 2016, $<$ www.burmalibrary.org/docs21/KWAT-2016-01-Justice_Delayed_Justice_Denied-en-red.pdf $>$, accessed 12
} 
been established, NGO representatives and lawyers, again sometimes with international support, have reported on trial processes and provided legal assistance. For example, the Dilibased JSMP was established to monitor the Law 26/2000 and SPs trials and continues to assess the Timor-Leste judicial system. ${ }^{138}$

NGOs have also sought to establish the 'value' of international criminal justice 'for local audiences'. ${ }^{139}$ The Indonesian Civil Society Coalition for the International Criminal Court (ICSCICC) argued that the Rome Statute protects Indonesian peacekeeping forces operating on the territory of states parties, ${ }^{140}$ just as the Philippines Coalition (PCICC) mentioned that the Statute could benefit Philippine workers living abroad. ${ }^{141}$ Similarly, politicians took the opportunity of the downing of Malaysia Airlines Flight MH17 over the Ukraine to discuss the benefits of Malaysia ratifying the Rome Statute. ${ }^{142}$ While officials are prompted to respect their international treaty obligations where relevant, across the region, NGO representatives also often refer to provisions under Constitutions and criminal codes. ${ }^{143}$

Civil society actors including NGOs and individuals have therefore advocated for international criminal justice using a range of arguments adjusted for domestic contexts, among other strategies. Beyond such advocacy, some communities have suggested that

\footnotetext{
March 2018; FORUM-Asia, HRC 31 Side Event - Time for Justice and Accountability: Rape, Sexual Violence and Burma/Myanmar's Ethnic Conflicts, 10 March 2016, <www.forum-asia.org/?p=20341>, accessed 12 March 2018.

${ }^{138}$ E.g., C. Sperfeldt, 'Cambodian civil society and the Khmer Rouge Tribunal', 6(1) International Journal of Transitional Justice (2012) 149-160.

${ }^{139}$ Acharya, supra note 9, p. 251.

${ }^{140}$ ICSCICC, Progress Report: Indonesia Efforts to Ratify the 1998 Rome Statute of the International Criminal Court, 14 December 2012, <advokasi.elsam.or.id/assets/2015/09/201211_Progress-Report_Indonesia-effort-toratify-1998-Rome-Statute.pdf >, accessed 12 March 2018, p. 10.

${ }^{141}$ PCICC, supra note 109, p. 3.

${ }^{142}$ E.g., M Kula Kulasegaran, Now the time than ever before for Malaysia to become a member of International Criminal Court (ICC) and make those who shot down MH17 to be accountable, 1 August 2015, $<$ ipohbaratvoice.blogspot.com.au/2015/08/now-time-than-ever-before-for-malaysia.html>, accessed 12 March 2018.

${ }^{143}$ E.g., PCICC, In Search for Justice: Commemorating 60 years of the Geneva Conventions, 12 August 2009, $<$ pcicc.wordpress.com/2009/08/12/in-search-for-justice-commemorating-60-years-of-the-geneva-conventions/>, 12 March 2018.
} 
taxation reform, ${ }^{144}$ land reform, ${ }^{145}$ reparations or other economic and social rights ${ }^{146}$ are priorities. Others have developed platforms that allow victims to share their experiences, including via public hearings, such as during KKPK's 'Year of Truth', ${ }^{147}$ the Cambodian Defenders Project Women's Hearings, ${ }^{148}$ and the IPT 1965. Alongside the SPs, Community Reconciliation Processes in Timor-Leste also reconstructed customary reconciliation practices in response to past violence. ${ }^{149}$ None of these initiatives has necessarily met its goals, ${ }^{150}$ and they should not be romanticised, ${ }^{151}$ but they demonstrate that actors have drawn on varied contexts to adapt their responses to international crimes.

These activities move past rejecting or accepting international criminal justice norms to generate novel responses to international crimes, or produce new spaces for advocacy. The Rome Statute and ICC are highly influential throughout Southeast Asia. However, to focus only on the influence of 'external' actors and instruments neglects the agency of regional political actors and the processes by which they interact.

\section{Adjusting for Time, Space and Direction}

This analysis has several repercussions for analysing political and legal questions about how states respond to international crimes. The first is that the progressive influence of international criminal justice should not be presumed. Yet, rather than rejecting international criminal justice norms entirely, different actors also reconstruct responses to international crimes. Removing the expectation of temporal progression simply acknowledges that states

\footnotetext{
${ }^{144}$ E.g., Network for Human Right Documentation-Burma (ND-Burma), The Hidden Impact of Burma's Arbitrary \& Corrupt Taxation, May 2010, <nd-burma.org/reports/the-hidden-impact-of-burmas-arbitrary-a-corrupttaxation/>, accessed 12 March 2018.

${ }^{145}$ E.g., PCICC, Laying Justice on the Ground: Moving from Land Disputes to Land Rights: Reports from the Breaking Barriers to Peace Project - Philippine Coalition for the International Criminal Court, 2014; ND-Burma, To Recognize and Repair: Unofficial Truth Projects and the Need for Justice in Burma, 8 June 2015, <ndburma.org/reports/to-recognize-and-repair/>, accessed 12 March 2018.

${ }^{146}$ KKPK, Menemukan Kembali Indonesia, 2014, <asia-ajar.org/2016/02/menemukan-kembali-indonesia/ >, accessed 12 March 2018.

${ }^{147}$ S.L. Wahyuningroem, 'Seducing for Truth and Justice: Civil Society Initiatives for the 1965 Mass Violence in Indonesia', 32(3) Journal of Current Southeast Asian Affairs (2013) 115-142.

${ }^{148}$ Ye, supra note 130.

${ }^{149}$ L. Kent, The Dynamics of Transitional Justice: International Models and Local Realities in East Timor (Routledge, Abingdon, 2012).

${ }^{150}$ Ibid.

${ }^{151}$ In particular, customary or hybrid and localised approaches may perpetuate inequalities, including by excluding marginalised groups including women, see Clarke, supra note 56, p. 131; Drexler, supra note 56; Kent, supra note 149.
} 
take different approaches in relation to different violent incidents - and policy positions can and do change.

Actors operating within diverse and changing social structures also influence international criminal justice in ways that cut across local and international divides. Grouping actors as 'local' or 'international' can help to reveal divergent understandings of international norms. However, these placeholders must not mask heterogeneity, the potential for movement across these categorisations, or other axes for tension. It may be more useful to understand stakeholders' potential influence by considering their interests, arguments and access to various forums of debate and influence, while also recognising that these elements can change. Recognising this complexity avoids characterising Southeast Asia as an international laggard without appreciating the initiatives for pursuing justice that already exist. ${ }^{152}$

This suggests some potential for the normative project of international criminal justice, not because of its inherent progressiveness, but due to the resistance that it can inspire. Frictions between different actors and ideas might stimulate change, rather than only indicating the rejection of international norms. ${ }^{153}$ States and civil society actors in Southeast Asia have produced diverse responses to international crimes, including joining the ICC, adopting laws, and establishing non-criminal mechanisms. Various actors are already working within domestic structures to overcome barriers and leverage opportunities, for instance by pursuing responses under domestic legislation or through media campaigns. Determining which consequences of such friction might be 'productive' is subjective, however. Stakeholders' own backgrounds and preconceptions inevitably shape their approaches toward violence. ${ }^{154}$ Yet even for those with a commitment to the Rome Statute ideals, resistance and pluralism, like sovereignty, are not necessarily the enemy, but represent contexts for friction and change.

Finally, the Rome Statute and notions of international criminal justice have influenced how some Southeast Asian states have responded to international crimes, including by providing a model for domestic legislation. This is despite the reality that the ICC (apart from its former

\footnotetext{
${ }^{152}$ Regarding the ICC and Uganda, see Clarke, supra note 56, p. 120.

153 Tsing, supra note 68, p. 5.

${ }^{154}$ See I. Hamati-Ataya, 'Reflectivity, reflexivity, reflexivism: IR's "reflexive turn" - and beyond', 19(4) European Journal of International Relations (2012) 669-694.
} 
President) has dedicated little attention to Southeast Asia relative to, for example, crimes committed in Africa. This has prompted some claims that pursuing investigations in Southeast Asia could provide one route for the ICC Prosecutor to avoid accusations of a bias toward prosecuting crimes in Africa, even though potential cases in Cambodia and the Philippines were promoted in part by 'local' actors. ${ }^{155}$ Thus, the internal politics of the ICC and the Security Council, which has so far not referred any situations in Southeast Asia to the Court - may affect the engagement of states in Southeast Asia with international criminal law and institutions.

Looking forward, if 'states strengthen domestic systems primarily for the sake of adjudicating specific cases domestically [rather than at the ICC], reform efforts are geared towards ICC priorities rather than long-term domestic interests'. ${ }^{156}$ On the other hand, communities, parliamentarians, and other 'local' actors have, and will continue to have, considerable influence upon states' responses to international crimes in the region, even if domestic proceedings are inspired by fears of an ICC investigation. This suggests that the power to shape discourse about international criminal justice arises from multiple shifting sources. ${ }^{157}$

\section{Conclusion}

Several benefits arise from analysing international criminal justice as involving dynamic aspects of power and friction, rather than arising from 'local' actors accepting 'international' ideas over time. It helps to: reveal how both barriers and opportunities can be compounded across geographic borders; encourage the recognition of heterogeneity and change ('local' actors disagree and have differing levels of influence, just as international organisations and states do); and therefore avoid equating a failure to prosecute international crimes with local unwillingness or lack of capacity without further questioning. Instead, experiences of international criminal justice in Southeast Asia suggest that categories such as global and local are better viewed as mutually constitutive and dynamic points of perspective, rather

155 T. Cruvellier, 'The ICC, Out of Africa', New York Times, 6 November 2016, <www.nytimes.com/2016/11/07/opinion/the-icc-out-of-africa.html?_r=0>, accessed 12 March 2018.

156 Stahn, supra note 76 , p. 74.

${ }^{157}$ Björkdahl et al, supra note 53, p. 26. 
than as defined and fixed labels. ${ }^{158}$ Moreover, approaches to international crimes can and do arise from complex sources of authority.

This analysis has implications for those advocating for international criminal justice in the region ${ }^{159}$ - that is, for state or civil society actors with a political and normative commitment toward prosecuting international crimes. First, context and experiences matter. Both the Rome Statute's complementarity principle and the improbability of ICC prosecutions across Southeast Asia occurring in the near future (particularly as a result of any Security Council referral) suggest that future prosecutions of international criminal conduct are more likely to occur within domestic jurisdictions, whether under specific 'international crimes' legislation or ordinary criminal codes. In order for such crimes to be investigated, let alone for fair trials to be carried out, investigators and judiciaries must be sufficiently independent and have the technical capacities to pursue such prosecutions, including proving the additional elements of international crimes, overcoming political barriers to prosecuting influential figures, and ensuring the security of witnesses. The problems faced by the ECCC, SPs and the Law 26/2000 trials demonstrate these challenges. However, capacity building activities are unlikely to shift state positions alone. Such initiatives have been pursued across the region for many years, with varied success (compare the impact of Rome Statute capacity-building in Lao PDR and Timor-Leste). Indeed, approaches focused only upon ‘education' represent assumptions that may deny local agency.

In fact, actors are already pursuing international criminal justice across Southeast Asia, or projects with similar goals. For those advocating for international crimes prosecutions, a complementary approach to promoting accession to the Rome Statute would learn from and progress existing relevant initiatives. ${ }^{160}$ This expertise provides opportunities for crossregional NGO, parliamentary, judicial, and investigative experience sharing. This may relate to the prosecutions that have occurred, including before the SPs, ECCC, and under Law $26 / 2000$, as well as the processes adopted for drafting and enforcing domestic legislation, such as the Philippine's international crimes legislation. International groups such as the

\footnotetext{
158 Buckley-Zistel, supra note 8 .

${ }^{159}$ See E. Palmer and C. Sperfeldt, 'International Criminal Justice and Southeast Asia: Approaches To Ending Impunity for Mass Atrocities', $126 \quad$ AsiaPacific Issues $<$ www.eastwestcenter.org/publications/international-criminal-justice-and-southeast-asia-approaches-endingimpunity-mass $>$, accessed 12 March 2018.

${ }^{160}$ Ibid.
} 
Asia-Pacific division of CICC and Parliamentarians for Global Action, and national networks such as the PCICC and ICSCICC, are already pursuing such initiatives.

International actors also play an important role in advocating for international crimes prosecutions. The ICC could expand regional consultations with NGOs and official actors now to learn about relevant domestic priorities and concerns about prosecuting international crimes. This would greatly improve the ICC Prosecutor's networks and knowledge should she decide to further investigate alleged international crimes within Southeast Asia and potentially help to avoid some of the complexities her Office has faced when investigating crimes in Africa.

The potential influence of a range of actors located in diverse and shifting spaces must be taken into account when analysing international criminal justice. This article offers a point of embarkation: rather than analysing the transfer of international criminal justice norms toward receptive states, how does one imagine international criminal law as an atemporal (dynamic), non-located (yet cognisant of spatial structures) and multi-directional (plural) phenomenon? This involves moving away from a 'local' or 'international' perspective toward one of shifting viewpoints that anticipates multiple understandings. Thus, it calls for a more nuanced appreciation for the multiple and dynamic ways that actors engage with each other and international criminal law. 